Mawaizh

Jurnal Dakwah dan Pengembangan Sosial Kemanusiaan

Vol. 11, no. 1 (2020), pp. 1-25.

DOI: https://doi.org/10.32923/maw.v11i1.1203

\title{
Menafsir Makna “Jihad” dalam Konteks Kekinian
}

\author{
Didi Junaedi \\ IAIN Syekh Nurjati Cirebon, Indonesia \\ Junaedi.didi1979@gmail.com
}

\begin{abstract}
This article aims to explore the meaning of jihad in the perspective of contextual interpretation. In this study, the Mawdlu' 'ì (thematic) Tafsir method used to catch a big picture or spirit of text, with the tool as a analysis tool in the form of two approaches, namely: Historical (Historical) and Hermeneutic Approaches. From the results of the study, get conclusion that jihad, which has often been reduced by some people as a war against different beliefs (the others), turns out to have a far more substantial meaning and is relevant to the present context. The meaning of the author is that jihad strives to uphold human values, oppose tyranny, uphold justice. In this case, jihad is broadly interpreted not merely as a war against the enemy, but to fight against injustice, tyranny, social pathoologies such as poverty, ignorance, and most importantly, jihad against oneself.
\end{abstract}

Keywords; Contextual, Interpretation, Jihad.

\begin{abstract}
Abstrak
Artikel ini bertujuan untuk mengupas makna jihad dalam perspektif tafsir kontekstual. Dalam kajian ini, penulis menggunakan metode Tafsir Mawdlū' (tematik), dengan alat bantu sebagai pisau analisis berupa dua pendekatan, yaitu: Pendekatan Sejarah (Historis) dan Pendekatan Hermeneutik. Dari hasil kajian penulis simpulkan bahwa jihad yang selama ini sering direduksi maknanya oleh sebagian orang sebagai perang melawan yang berbeda keyakinan (the others; liyan), ternyata memiliki makna yang jauh lebih substansial dan relevan dengan konteks kekinian. Makna yang penulis maksud adalah jihad berjuang menegakkan nilai-nilai kemanusiaan, melawan kezaliman, menegakkan keadilan. Dalam hal ini jihad dimaknai secara luas tidak semata-mata perang melawan musuh, tetapi berjuang melawan ketidakadilan, tirani, penyakit sosial seperti kemiskinan, kebodohan, dan yang terpenting adalah jihad melawan diri sendiri.
\end{abstract}

Kata Kunci; Tafsir, Jihad, Kontekstual.

Accepted: 18-04-2020; reviewed: 18-05-2020; published: 04-06-2020

Citation: Didi Junaedi, 'Menafsir Makna "Jihad" dalam Konteks Kekinian', Mawa'izh: Jurnal Dakwah dan Pengembangan Sosial Kemanusiaan, vol. 11, no. 1 (2020), pp. 1-25. 
Mawa'izh

Jurnal Dakwah dan Pengembangan Sosial Kemanusiaan

Vol. 11, no. 1 (2020), pp. 1-25.

DOI: https://doi.org/10.32923/maw.v11i1.1203

\section{A. Pendahuluan}

udah menjadi keniscayaan sejarah bahwa umat Islam senantiasa berusaha
menjadikan al-Qur'ān sebagai "teman diskusi” dan "kawan dialog" dalam menjalani
proses sejarah kehidupan. Mereka berusaha mendialogkan teks-teks al-Qur'ān dengan realitas kehidupan yang sedang berlangsung dan mereka alami. Proses dialektika antara teks yang terbatas dan konteks yang tidak terbatas inilah yang pada gilirannya melahirkan dan memicu munculnya tafsir dengan multi perspektif.

Semaraknya khazanah tafsir dengan pelbagai perspektif, yang pada gilirannya meniscayakan lahirnya pluralitas tafsir ini menjadi sebuah 'aset' berharga dan harus terusmenerus dikembangkan. Dalam pelbagai literatur yang mengungkap tentang sejarah penafsiran al-Qur'ān, ${ }^{1}$ kita menjumpai beragam metode dan model penafsiran disertai beraneka corak dan karakteristik yang menunjukkan ciri khas mufasir-terkait dengan latar subyektif yang melekat pada diri mufasir-, meliputi: background teologis serta disiplin ilmu yang mereka kuasai dan konteks zaman situasi sosio-kultural-historis, bahkan kondisi politik, dimana seorang mufasir hidup. Dengan demikian, maka adanya pluralitas penafsiran al-Qur'ān adalah wajar-wajar saja, sepanjang dapat dipertanggungjawabkan secara ilmiah dan moral.

Sejauh pengamatan penulis, secara garis besar dalam lintasan sejarah penafsiran alQur'ān terdapat dua kelompok atau dua model penafsiran dengan kecenderungan dan orientasi yang berbeda satu sama lain. Kelompok pertama, yaitu mereka yang berusaha menafsirkan al-Qur'ān dengan kecenderungan atau orientasi tekstual (al-ittijāh al-nashshī) semata, dan kurang atau bahkan tidak mengindahkan sama sekali konteks yang melingkupi teks tersebut. Mereka memandang nashsh (teks) al-Qur'ān adalah sesuatu yang final dan harus diterima tanpa reserve.

1 Beberapa literatur yang dapat kita jadikan sebagai referensi dalam hal ini antara lain: Muhammad Husain al-Dzahabī, Al-Tafsīr wa al-Mufassirūn, (Cairo: Maktabah Wahbah, 1995), Muhammad 'Ali 'Iyāzī, AlMufassirūn; Hayātuhum wa Manhajuhum, (Teheran: Mu'assasah al-Thibā'ah wa al-Nasyr Wizārat al-Tsaqāfah

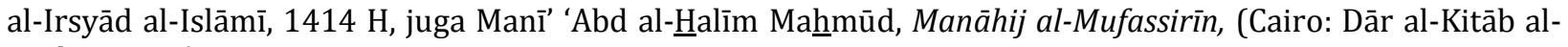
Mishrī, 1978). 
Mawa'izh

Jurnal Dakwah dan Pengembangan Sosial Kemanusiaan

Vol. 11, no. 1 (2020), pp. 1-25.

DOI: https://doi.org/10.32923/maw.v11i1.1203

Kelompok ini seringkali menafikan sisi historisitas yang melingkupi teks tersebut, dimana, kapan, dan mengapa teks tersebut lahir. Penafsiran kelompok pertama ini cenderung mengabaikan kondisi riil kehidupan yang sedang mereka jalani. Sehingga seringkali penafsiran yang dihasilkan, alih-alih memberikan solusi terhadap problematika kehidupan yang sedang dihadapi, justru melahirkan problem baru.

Kelompok kedua, yaitu mereka yang berusaha menafsirkan al-Qur'ān dengan kecenderungan orientasi kontekstual (al-ittijāh al-wāqiîi). Mereka memandang teks alQur'ān sebagai al-turāts (warisan) khazanah Islam yang tidak lepas dari sisi sosio-historis. Kehadirannya merupakan fenomena sejarah dan memiliki konteks spesifik. Lebih lanjut, kelompok ini melihat bahwa al-Qur'ān tidak lahir dalam ruang hampa budaya, tapi lahir dalam ruang-waktu yang sarat budaya.

Dengan demikian, menurut kelompok kedua ini penafsiran terhadap al-Qur'ān harus mengacu pada realitas yang melingkupinya. Penafsiran secara tekstual tanpa memperhatikan sisi sosio-historis di mana teks tersebut lahir, hanya akan menghadirkan tafsir yang kaku dan beku karena tidak dapat berdialektika dengan realitas masyarakat. Singkatnya kelompok ini menekankan bahwa menafsir al-Qur'ān secara konteksual adalah sesuatu yang niscaya. Belakangan kelompok ini dikenal dengan istilah kaum liberal.

Dalam kajian selanjutnya, penulis akan memfokuskan bahasan tentang eksistensi kelompok kedua, yakni mereka yang menitikberatkan orientasi kontekstual (al-ittijāh alwāqi'i ) dalam penafsiran al-Qur'an yang menurut hemat penulis lebih sesuai dengan semangat zaman. Model penafsiran seperti inilah, yang kelak diharapkan mampu memberikan gambaran tentang konsep Islam sebagai rahmatan lil 'alamin.

Dalam tulisan ini penulis mengambil term "jihad" sebagai tema bahasan. Sebuah term yang kerap memicu perbedaan pendapat dan perdebatan di kalangan umat Islam sendiri. Penulis berusaha untuk menguraikan sejumlah ayat tentang "jihad" disertai tinjauan kritis dengan pendekatan sejarah dan hermeneutik. 
Mawaizh

Jurnal Dakwah dan Pengembangan Sosial Kemanusiaan

Vol. 11, no. 1 (2020), pp. 1-25.

DOI: https://doi.org/10.32923/maw.v11i1.1203

\section{B. Metode Penafsiran}

Dalam kajian ini, penulis menggunakan metode Tafsir Mawdlūī (tematik), dengan alat bantu sebagai pisau analisis berupa dua pendekatan, yaitu: Pendekatan Sejarah (Historis) dan Pendekatan Hermeneutik.

\section{Metode Tafsīr Mawdlū'ī}

Tafsīr mawdlū'î adalah suatu metode tafsir yang berusaha mencari jawaban al-Qur'ān tentang tema tertentu, maka tafsir ini juga dinamakan tafsir tematik. Pelbagai definisi dikemukakan oleh sejumlah sarjana Muslim berkenaan dengan metode tafsīr mawdlū'î.

Ziyād Khalīl Muhammad al-Daghamain ${ }^{2}$ mendefinisikan tafsīr mawdlūî̀ dengan: sebuah metode tafsir al-Qur'ān dengan cara menghimpun ayat-ayat al-Qur'ān yang mempunyai maksud yang sama dan meletakkannya dalam satu tema atau satu judul.

Musthafa Muslim ${ }^{3}$ memahaminya sebagai sebuah metode tafsir dengan cara membahas tema-tema sesuai dengan maksud-maksud al-Qur'ān dari satu surat atau lebih. Sedangkan al-Farmāwī memberikan sebuah pengertian bahwa yang dimaksud dengan tafsīr mawdlū'î adalah menghimpun ayat-ayat al-Qur'ān yang mempunyai maksud yang sama dalam arti sama-sama membicarakan satu topik masalah dan menyusunnya berdasar kronologi serta sebab-sebab turunnya ayat tersebut. ${ }^{4}$

Dari beberapa pengertian tentang tafsīr mawdlūî di atas, dapat disimpulkan bahwa metode tafsīr mawdlū'ì (tematis) adalah sebuah upaya memahami dan menjelaskan kandungan ayat al-Qur'ān dengan cara menghimpun ayat-ayat dari berbagai surah yang berkaitan dengan satu topik, lalu dianalisa kandungan ayat-ayat tersebut hingga menjadi satu kesatuan konsep yang utuh.

\footnotetext{
2Ziyad Khalil Muhammad al-Daghamain, Manhajiyyah al-Bahts fĩ al-Tafsīr al-Maudhū'̄i, (Amman: Dār al-Basyar, 1995), p. 14

${ }^{3}$ Musthafa Muslim, Mabāhits fĩ al-Tafsīr al-Maudhū'̄i, (Damaskus: Dār al-Qalam, 1989), p. 16

4، 'Abd al-Hayy al-Farmāwī, Al-Bidāyah fì al-Tafsīr al-Mawdlū'̄i; Dirāsah Manhajiyyah Mawdlū'iyyah, (Cairo: Al-Hadhārah al-'Arabiyyah, 1977), p. 52
} 
Mawa'izh

Jurnal Dakwah dan Pengembangan Sosial Kemanusiaan

Vol. 11, no. 1 (2020), pp. 1-25.

DOI: https://doi.org/10.32923/maw.v11i1.1203

Al-Farmāwī menegaskan bahwa kitab-kitab terdahulu juga banyak yang menggunakan metode tafsir yang mendekati tafsīr mawdlū'î, hanya saja masih dalam bentuk yang sederhana, dan belum dapat dikatakan sebagai sebuah metode yang berdiri sendiri. Beberapa kitab tersebut antara lain; Majāz al-Qur'ān, karya Abu 'Ubaidah (w. 209 H) yang berbicara berbagai majaz (kiasan) dalam al-Qur'ān. Al-Jashshāsh (w. 370 H) dengan A $\underline{h} k \bar{a} m$ al-Qur'ān yang membahas tentang persoalan dalam al-Qur'ān, juga Ibn Qayyim (w. 751 H) dengan al-Bayān fì Aqsām al-Qur'ān yang khusus membicarakan sumpah-sumpah dalam alQur'ān dan lain-lainnya.5

Tafsīr mawdlū'ī sebagai suatu ilmu atau sebuah metode penafsiran tersendiri adalah istilah yang baru muncul pada abad ke-14 Hijriyah, tepatnya ketika untuk pertama kalinya Prof. Dr. Ahmad Sayyid al-Kumy, Ketua Jurusan Tafsir pada Fakultas Ushuluddin Universitas Al-Azhar, Mesir, memasukkannya sebagai materi kuliah. ${ }^{6}$

Metode ini semakin menemukan bentuknya setelah al-Farmāwī, yang juga menjabat guru besar pada Fakultas Ushuluddin Al-Azhar, menerbitkan bukunya Al-Bidāyah fĩ al-Tafsīr al-Mawdlū'ì di Kairo pada tahun 1977.

Al-Farmāwī mengemukakan secara rinci langkah-langkah yang hendaknya ditempuh untuk menerapkan metode mawdlū'ì. Adapun langkah-langkah tersebut adalah:

a) menentukan tema masalah yang akan dibahas;

b) menghimpun ayat-ayat yang berkaitan dengan tema tersebut;

c) menyusun sekuensial ayat sesuai dengan kronologis turunnya, disertai pengetahuan tentang asbāb al-nuzūl;

d) memahami munāsabah (korelasi) ayat-ayat tersebut dalam surahnya masingmasing;

e) menyusun kerangka pembahasan yang sempurna (outline);

f) melengkapi pembahasan dengan hadis-hadis yang relevan;

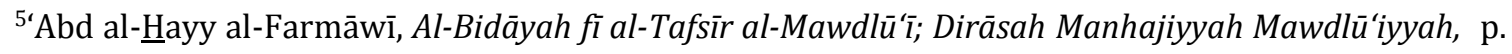

${ }^{6}$ Khālid 'Abdurraḥmān al-'Āk, Al-Furqān wa al-Qur'ān, (Beirut: Dār al-Hikmah, t. th.), p. 532. 
Mawa'izh

Jurnal Dakwah dan Pengembangan Sosial Kemanusiaan

Vol. 11, no. 1 (2020), pp. 1-25.

DOI: https://doi.org/10.32923/maw.v11i1.1203

g) meneliti ayat-ayat tersebut secara keseluruhan dengan cara menghimpun ayatayatnya yang mempunyai pengertian sama, atau mengompromikan antara yang 'ām (umum) dan yang khāsh (khusus), mutlak dan muqayyad (terikat), atau yang pada lahirnya bertentangan, sehingga kesemuanya bertemu dalam satu muara, tanpa perbedaan atau pemaksaan. ${ }^{7}$

M. Quraish Shihab ${ }^{8}$ menegaskan, dengan tersusunnya langkah-langkah sistematis yang dirancang oleh al-Farmāwī, maka lahirlah bentuk kedua dari metode tafsīr mawdlū'ī. Bentuk pertama, ialah penafsiran menyangkut satu surat dalam al-Qur'ān dengan menjelaskan tujuan-tujuannya secara umum dan khusus, serta hubungan persoalan-persoalan yang beraneka ragam dalam surat tersebut, sehingga kesemua persoalan saling terkait, bagaikan satu persoalan saja.

Kedua, menghimpun ayat-ayat al-Qur'ān yang membahas masalah tertentu dari berbagai surat al-Qur'ān, kemudian menjelaskan pengertian menyeluruh ayat-ayat tersebut, sebagai jawaban terhadap masalah yang menjadi pokok pembahasannya.

\section{Pendekatan Sejarah}

Tuhan menurunkan wahyu dalam konteks yang tidak hampa dari sejarah manusia dan interpretasi terhadap wahyu merepresentasikan unsur kesejarahan yang berlaku saat itu. ${ }^{9}$ Oleh karena itu, wahyu tidak saja memiliki nilai transendental yang bersifat abadi dan melampaui peristiwa-peristiwa, tetapi juga mengandung nilai-nilai transhistoris yang artinya wahyu diturunkan oleh Tuhan dalam sejarah. Karena itu wahyu Tuhan adalah respons yang konkrit terhadap sejarah, terhadap kurun waktu tertentu. ${ }^{10}$

Berangkat dari kenyataan ini, maka untuk menghadirkan nilai-nilai serta spirit (ruh) yang terkandung dalam sebuah wahyu, diperlukan penelusuran sejarah tentang kapan, di

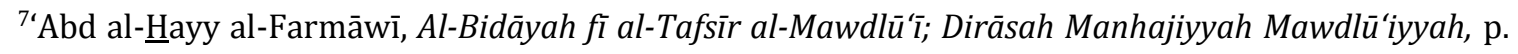

61.

${ }^{8}$ M. Quraish Shihab, Membumikan al-Qur'ān, (Bandung: Mizan), p. 117.

${ }^{9}$ Kennet Cragg, The Event of the Qur'an: Islam and its Scripture, (London: George Allen and Unwin, 1971), p. 17.

${ }^{10}$ Kuntowijoyo, Iman dan Realitas, (Yogyakarta: Shalahuddin Press, 1985), p. 21. 
Mawa'izh

Jurnal Dakwah dan Pengembangan Sosial Kemanusiaan

Vol. 11, no. 1 (2020), pp. 1-25.

DOI: https://doi.org/10.32923/maw.v11i1.1203

mana dan untuk siapa wahyu tersebut hadir. Tak pelak, tinjauan sejarah atau pendekatan historis dalam hal ini, adalah sebuah keniscayaan yang tidak dapat ditawar-tawar.

Dalam khazanah tradisional, aspek ini sebenarnya sudah disadari dengan adanya $a s b \bar{a} b$ al-nuzūl dalam proses penafsiran. Adanya asbāb al-nuzūl merupakan salah satu bentuk kesadaran bahwa teks agama tidak muncul di ruang hampa. Ada proses-proses sosial tertentu yang berperan dalam melahirkan sebuah teks. Namun sayangnya, dalam tafsir konservatif asbāb al-nuzūl ini cenderung dipahami secara ad hoc yang diletakkan dalam kerangka nalar bayānī untuk mendukung paham ortodoksi.

Berkaitan dengan historisitas teks ini ada beberapa hal yang perlu dilakukan dalam proses penafsiran, yaitu: Pertama, melakukan kritik sejarah terhadap situasi historis yang melingkupi lahirnya sebuah teks. Kritik sejarah ini tentu saja dapat dilakukan dengan menggunakan prinsip-prinsip ilmu sejarah. Sebagai kelanjutan dari kritik sejarah maka perlu juga dilakukan analisis sosial, baik yang berkaitan dengan situasi ketika teks lahir maupun situasi sosial yang kita hadapi. Kedua, kritik isi, yaitu melakukan kritik terhadap muatan makna yang terdapat dalam teks. Kritik isi ini bisa dilakukan dengan menggunakan instrumen kritik wacana untuk melihat wacana apa yang sebenarnya sedang berkerja dalam teks tersebut.

\section{Pendekatan Hermeneutik}

Sebelum melangkah lebih jauh pada kajian tentang tinjauan hermeneutik atas pelbagai term yang kerap memicu pertentangan di kalangan umat Islam, seperti term "Islam", "jihad" dan "non-Muslim", sebagaimana dibahas dalam bab sebelumnya, penulis ingin menguraikan terlebih dahulu apa yang dimaksud dengan hermeneutik, yang akhir-akhir ini semakin populer dalam ranah akademis? Dalam pelbagai literatur dijelaskan bahwa kata hermeneutik merupakan derivasi dari bahasa Yunani, dari akar kata hermeneuin, yang berarti menafsirkan. Dari kata hermeneuin ini dapat ditarik kata benda hermeneia yang 
Mawa'izh

Jurnal Dakwah dan Pengembangan Sosial Kemanusiaan

Vol. 11, no. 1 (2020), pp. 1-25.

DOI: https://doi.org/10.32923/maw.v11i1.1203

berarti "penafsiran" atau "interpretasi" dan kata hermeneutes yang berarti interpreter (penafsir). ${ }^{11}$

Hermeneutik ini berperan menjelaskan teks seperti apa yang diinginkan oleh si pembuat teks tersebut. Peran ini persis seperti figur Hermes yang bertugas membawakan pesan-pesan Tuhan Zeus kepada manusia. Karena peran inilah, maka kata hermeneutik ini sering diasosiasikan dengan nama dewa Yunani yang bernama Hermes tersebut. Dan dari fungsi serta peran ini pula hermeneutik mulai mendapatkan makna baru sebagai sains atau seni menafsir. Istilah hermeneutik dalam pengertian sebagai "ilmu tafsir" muncul pada sekitar abad ke-17, di mana istilah ini bisa dipahami dalam dua pengertian, yaitu hermeneutik sebagai seperangkat prinsip metodologis penafsiran, dan hermeneutik sebagai penggalian filosofis dari sifat dan kondisi yang diperlukan bagi semua bentuk pemahaman. ${ }^{12}$

Carl Braaten kemudian merangkum kedua pengertian ini menjadi satu dengan menyimpulkan bahwa hermeneutik adalah "ilmu yang mendeskripsikan bagaimana sebuah kata atau satu kejadian dalam masa dan budaya yang telah lalu, dapat dipahami dan bermakna secara nyata dalam situasi sekarang, dengan melibatkan aturan-aturan metodologis serta asumsi-asumsi epistemologis yang diterapkan dalam penafsiran".13

Sebagai sebuah metode penafsiran, hermeneutik tidak hanya terpaku pada persoalan teks yang diam atau bahasa sebagai struktur dan makna, tetapi secara perlahan ia mulai mendeskripsikan penggunaan bahasa atau teks dalam seluruh realitas hidup manusia. Hermeneutik juga tidak hanya memandang teks dan berusaha menyelami kandungan makna literalnya semata. Menurut Komaruddin Hidayat, hermeneutik berusaha menggali makna dengan mempertimbangkan variabel-variabel yang melingkupi teks tersebut. Variabelvariabel yang dimaksud adalah the world of the text, the world of the author, dan the world of the reader. Ketiga variabel tersebut masing-masing merupakan titik pusaran tersendiri,

\footnotetext{
${ }^{11}$ Mircea Eliade, The Encyclopedia of Religion, (New York: Macmillan, 1993), Vol. 5, p. 279. Lihat juga E. Sumaryono, Hermeneutika: Sebuah Metode Filsafat, (Yogyakarta: Kanisius, 1999), p. 23.

12 Richard E. Palmer, Hermeneutics: Interpretation Theory in Schleiermacher, Dilthey, Heidegger, and Gadamer, (Evanston: Northwestern University Press, 1969), p. 44.

13 Carl Braaten, History and Hermeneutics, (Philadelphia: Fortress, 1966), p. 131.
} 
Mawa'izh

Jurnal Dakwah dan Pengembangan Sosial Kemanusiaan

Vol. 11, no. 1 (2020), pp. 1-25.

DOI: https://doi.org/10.32923/maw.v11i1.1203

meskipun kesemuanya saling mendukung—bisa juga sebaliknya, membelokkan—dalam memahami sebuah teks. ${ }^{14}$

Dengan memperhatikan ketiga varibel tersebut diharapkan upaya penafsiran atau pemahaman menjadi suatu kegiatan rekonstruksi dan reproduksi makna teks. Yaitu sebuah upaya melacak kembali bagaimana suatu teks itu dihadirkan oleh pengarangnya serta muatan apa yang dimaksud oleh pengarang dalam teks tersebut, sekaligus melahirkan kembali makna tersebut sesuai dengan situasi dan kondisi saat teks tersebut dibaca atau dipahami. Dari pelbagai pengertian tentang hermeneutik di atas, dapat disimpulkan bahwa yang dimaksud dengan hermeneutik adalah sebuah metode interpretasi yang berupaya menafsir atau memahami maksud yang dikandung oleh sebuah teks, dengan memperhatikan berbagai variabel yang melingkupinya; dunia pengarang, dunia teks serta dunia pembaca.

Berkenaan dengan cara kerja metode hermeneutik ini, sejumlah ilmuwan mengemukakan beragam pendapat. Friedrich Ernst Daniel Schleiermacher (1768-1834), misalnya, yang kemudian disebut sebagai "Bapak Hermeneutik Modern"-karena membangkitkan kembali hermeneutik dan membakukannya sebagai metode umum interpretasi-menggunakan hermeneutik untuk memahami orisinalitas arti dari sebuah teks, bahkan lebih dari itu arti hermeneutik baginya adalah untuk memahami sebuah wacana (discourse) dengan baik, kalau perlu lebih baik dari si pembuatnya (to understand the discourse just well as well as and even better than its creator). ${ }^{15}$

Wilhelm Dilthey (1833-1911), sebagaimana dikutip E. Sumaryono, menegaskan bahwa hermeneutik pada dasarnya bersifat menyejarah. Artinya bahwa makna itu sendiri tidak pernah berhenti pada satu masa saja, tetapi selalu berubah menurut modifikasi sejarah. ${ }^{16}$ Pandangan Dilthey inilah, yang kemudian menjadikan metode hermeneutik-nya disebut dengan hermeneutik historis. 1996), p. 3.

${ }^{14}$ Komaruddin Hidayat, Memahami Bahasa Agama; Sebuah Kajian Hermeneutik, (Jakarta: Paramadina,

15 Lihat tulisan Friedrich D. E. Schleiermacher, "The Hermeneutics: Outline of the 1819 Lectures" dalam buku Gayle L. Ormiston dan Alan D. Schrift, Hermeneutic Tradition: From Ast to Ricoeur, (New York: SUNNY, 1990), p. 93.

${ }^{16}$ E. Sumaryono, Hermeneutika: Sebuah Metode Filsafat, p. 56. 
Mawa'izh

Jurnal Dakwah dan Pengembangan Sosial Kemanusiaan

Vol. 11, no. 1 (2020), pp. 1-25.

DOI: https://doi.org/10.32923/maw.v11i1.1203

Hassan Hanafī, seorang pemikir Muslim kontemporer berkebangsaan Mesir, menyatakan bahwa hermeneutik itu tidak sekadar "ilmu interpretasi" atau "teori pemahaman", tetapi juga ilmu yang menjelaskan penerimaan wahyu sejak dari tingkat perkataan sampai ke tingkat dunia. Ilmu tentang proses wahyu dari huruf sampai kenyataan, dari logos sampai praksis dan juga transformasi wahyu dari pikiran Tuhan kepada kehidupan manusia. ${ }^{17}$

Munculnya pelbagai definisi serta berkembangnya beragam persepsi tentang hermeneutik ini menunjukkan bagaimana kronologi pemahaman manusia terhadap hermeneutik. Namun demikian, secara umum dapat dikatakan bahwa hermeneutik merujuk pada teori penafsiran, baik yang ditafsirkan itu teks atau sesuatu yang diperlakukan sebagaimana teks.

Pertanyaannya kemudian jika dikaitkan dengan teks Kitab Suci yang dianggap oleh mayoritas umat beragama sebagai sesuatu yang sakral, apakah metode hermeneutik ini juga dapat diterapkan sebagai metode penafsiran terhadap Kitab Suci tersebut? Khususnya bagi Kitab Suci umat Islam yaitu al-Qur'ān, apakah hermeneutik ini juga dapat dijadikan sebagai metode penafsiran? Lantas apa bedanya dengan Tafsìr yang selama ini sudah dikenal sebagai sebuah metode yang mapan dalam memahami al-Qur'ān?

Tidak dapat dipungkiri, hermeneutik adalah istilah baru dalam wacana Muslim tentang al-Qur'ān. Term khusus yang telah mapan dan digunakan dalam kegiatan interpretasi terhadap al-Qur'ān adalah "tafsīr" yang merupakan derivasi dari kata "fassara" atau "fasara" yang mengandung pengertian eksegesis di kalangan umat Islam dari masa klasik hingga sekarang.

Meskipun demikian ketiadaan istilah hermeneutik yang definitif dalam khazanah Islam klasik dan tidak dipakainya istilah tersebut secara luas dalam literatur kontemporer alQur'ān, bukan berarti praktik operasional hermeneutik tersebut tidak ada pada masa klasik. Menurut Farid Esack, praktik operasional yang bersifat hermeneutikal sebenarnya telah

1.

${ }^{17}$ Hasan Hanafi, Dialog Agama dan Revolusi, terj. Pustaka Firdaus, (Jakarta: Pustaka Firdaus, 1994), p. 
Mawa'izh

Jurnal Dakwah dan Pengembangan Sosial Kemanusiaan

Vol. 11, no. 1 (2020), pp. 1-25.

DOI: https://doi.org/10.32923/maw.v11i1.1203

dilakukan umat Islam sejak lama, khususnya ketika menghadapi al-Qur'ān. Bukti akan hal ini adalah:

1. Problem hermeneutik senantiasa dialami dan diselesaikan secara aktif, meski tidak dihadapi secara tematis. Ini terbukti dari diskusi-diskusi tentang asbāb al-nuzūl dan nāsikh-mansūkh.

2. Perbedaan antara tafsiran aktual dengan aturan, teori atau metode interpretasi yang mengaturnya sudah ada dalam literatur-literatur awal tafsir.

3. Tafsir tradisional telah dikategorisasi. Beberapa kategori seperti "tafsir Syi'ah", "Mu'tazilah", "Asy’ariah", "hukum", "filsafat", dan sebagainya menunjukkan afiliasi, ideologi, dan aspek historis penafsir. ${ }^{18}$

Dari keterangan Farid Esack di atas, jelaslah bahwa pada hakekatnya operasional hermeneutik telah berjalan sejak lama. Meskipun demikian, operasional hermeneutik secara utuh seringkali ditentang oleh ilmuwan Islam tradisional khususnya, dan umat Islam tradisional pada umumnya. Penentangan serta penolakan ini didasari oleh cara kerja hermeneutik yang setidaknya membawa tiga macam implikasi yang bertentangan dengan pandangan para ilmuwan serta umat Islam tradisional tersebut. Tiga macam implikasi tersebut adalah:

1. Hermeneutik meniscayakan keterlibatan konteks dan kondisi manusia. Ini berarti bahwa al-Qur'ān bukanlah sesuatu yang berada di luar konteks sosio-historisnya. Singkatnya tanpa konteks teks itu tidak berarti apa-apa. Sedangkan ide tradisional menyatakan bahwa makna yang sebenarnya itu adalah apa yang dimaksud oleh Allah.

2. Hermeneutik menekankan bahwa yang menghasilkan makna itu adalah manusia. Sedangkan pandangan tradisional menyatakan bahwa Tuhanlah yang menganugerahkan pemahaman yang benar terhadap seseorang.

3. Berbeda dengan tradisi hermeneutik, ilmuwan tradisional Islam telah membuat pembedaan ketat dan seolah tak terjembatani antara pewahyuan di satu sisi 
Mawa'izh

Jurnal Dakwah dan Pengembangan Sosial Kemanusiaan

Vol. 11, no. 1 (2020), pp. 1-25.

DOI: https://doi.org/10.32923/maw.v11i1.1203

dengan interpretasi dan penerimanya di sisi lain. Teks al-Qur'ān dianggap sangat sakral sehingga makna yang sebenarnya tidak mungkin bisa dicapai. ${ }^{19}$

\section{Menelusuri Jejak Makna Jihad dalam Al-Qur'an Ala Kontekstualis}

Jika kelompok skripturalis memaknai jihad sebagai "perang suci", maka kelompok kontekstualis memaknai jihad sebagai sebuah perjuangan terhadap nilai-nilai kemanusiaan seperti penegakan keadilan, persamaan hak, pembebasan terhadap segala bentuk penindasan dan sederet persoalan kemanusiaan lainnya yang pada akhirnya bermuara pada pengejawantahan nilai-nilai ketuhanan di muka bumi.

Berikut penulis paparkan uraian mengenai penafsiran kelompok kontekstualis dalam memaknai sejumlah ayat yang berkenaan dengan masalah jihad. Beberapa ayat yang telah penulis petakan tentang masalah ini, seperti pada pembahasan sebelumnya, antara lain terdapat dalam Q., s. al-Taubah/9: 29, 38 dan 39, Q., s. al-Furqān/25: 52 dan Q., s. al'Ankabūt/29: 69. Namun demikian tidak menutup kemungkinan penulis menjumpai ayatayat lain tentang tema jihad ini yang dikemukakan oleh kalangan kontekstualis sebagai dasar argumen mereka. Perintah jihad telah turun melalui ayat-ayat al-Qur'ān semenjak Nabi Muhammad Saw berdakwah Islam di Makkah. Namun pemakaian kata-kata jihad tidak bermakna perang dan perlawanan fisik, jihad dipakai dalam makna perjuangan yang substantif, etis, moral, dan spiritual.

Para ahli tafsir berbeda pendapat tentang makna Firman Allah Swt. dalam Q.s. alFurqān/25: 52 yang menyebutkan:

$$
\text { فلا تطع الكفرين وجهاهم جهادا كبيرا (الفرقان /25: 52) }
$$

Maka janganlah kamu mengikuti orang-orang kafir, dan berjihadlah terhadap mereka dengan jihad yang besar.

${ }^{19}$ Ibid. 
Mawa'izh

Jurnal Dakwah dan Pengembangan Sosial Kemanusiaan

Vol. 11, no. 1 (2020), pp. 1-25.

DOI: https://doi.org/10.32923/maw.v11i1.1203

Perbedaan pendapat itu terletak pada makna dengan apa berjihad? Menurut Ibn 'Abbās sebagaimana dikutip oleh Ibn Katsīr, konotasi makna jihad dalam ayat itu adalah dengan "al-Qur'ān". ${ }^{20}$ Ibn Zayd menyebutnya dengan "Islam" dan ada juga yang berpendapat dengan "pedang". ${ }^{21}$ Pendapat terakhir yaitu jihad dengan "pedang" ditolak secara keras oleh al-Qurthubī karena menurutnya ayat ini turun di Makkah jauh sebelum turun perintah perang. Al-Zamakhsyarī menambahkan bahwa makna "jihad yang besar" adalah mencakup segala bentuk perjuangan (jāmi'an likulli mujāhadah).22

Dalam ayat lain disebutkan tentang keberadaan jihad di Makkah. Firman Allah Swt dalam Q., s. al-'Ankabūt/29: 69 menegaskan:

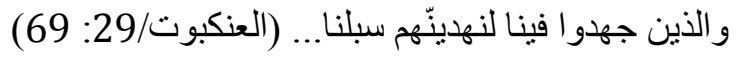

Dan orang-orang yang berjihad untuk mencari (keridlaan) Kami, benar-benar akan Kami tunjukan kepada mereka jalan-jalan Kami.

Menurut al-Zamakhsyarī, ayat ini tidak memiliki spesifikasi objek (maf'ül) perjuangan. Artinya bahwa jihad (perjuangan) memiliki cakupan luas baik jihad terhadap dorongan jiwa yang tercela, setan, ataupun musuh agama. ${ }^{23}$ Dengan demikian, makna jihad dalam ayat ini sesuai dengan kondisi sosial umat Islam di Makkah pada saat itu adalah berjuang di jalan Allah dengan penuh kesabaran, menanggung penderitaan akibat cacian dan siksaan kaum Quraisy. Dengan perjuangan mereka Allah akan memberi petunjuk dan menerangi jalan-jalan-Nya.

Farid Esack menyebutkan bahwa melalui ayat ini al-Qur'ān memberikan penekanan besar pada ortopraksis dan menegaskan bahwa jihad dan kebaikan adalah juga jalan menuju pemahaman dan pengetahuan. Al-Qur'ān menetapkan jihad sebagai jalan untuk menegakkan keadilan, dan praksis sebagai jalan untuk memperoleh dan memahami kebenaran. $^{24}$

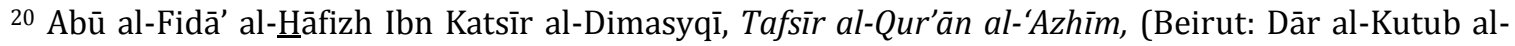
'Ilmiyyah, 2000), Jilid III, p. 326.

${ }^{21}$ Al-Qurthubī, Al-Jāmi' li A $\underline{h} k a ̄ m$ al-Qur'ān, (Beirut: Dār al-Fikr, 1995), Jilid VII, p. 56.

${ }^{22}$ Al-Zamakhsyarī, Al-Kasysyāf, (Kairo : Mushthafa al-Babi al-Halabi, 1996) Juz III, p. 96.

${ }^{23}$ Al-Zamakhsyarī, Al-Kasysyāf,, (Kairo : Mushthafa al-Babi al-Halabi, 1996) Juz III, p. 213.

${ }^{24}$ Farid Esack, Qur'an: Liberation \& Pluralism, (Oxford: One World, 1997), p. 107. 
Mawa'izh

Jurnal Dakwah dan Pengembangan Sosial Kemanusiaan

Vol. 11, no. 1 (2020), pp. 1-25.

DOI: https://doi.org/10.32923/maw.v11i1.1203

Dari pandangan Esack tersebut, dapat dikatakan bahwa ayat ke-69 dari surat al'Ankabūt di atas menegaskan bahwa al-Qur'ān mengajarkan kepada para aktivis yang beriman untuk mewujudkan tauhid, takwa, dan memberi perubahan yang konkret bagi kaum tertindas melalui jihad (perjuangan terhadap nilai-nilai kemanusiaan). Hal ini seperti apa yang dikatakan oleh Ayatullah Mahmūd Taleghānī (w. 1979), "jalan Tuhan adalah jalan yang mengarah pada kebaikan bagi seluruh manusia, jalan keadilan, jalan kemerdekaan manusia agar tak satu kelompok pun menjadi dominan..."25

Muhammad Syahrūr memaknai jihad di jalan Allah (jihād fi sabīlillāh) sebagai perjuangan dalam menegakkan pesan-pesan-Nya yang mulia yaitu perjuangan melawan tirani, perjuangan mengampanyekan kebebasan, serta perjuangan dalam menghilangkan pemaksaan kepada siapapun dan atas dalih apapun. ${ }^{26}$ Sedangkan menurut Khaled Abou El Fadl, jihad adalah berupaya keras atau berjuang untuk mencari keadilan. Perang suci (alharb al-muqaddasah) bukan merupakan istilah yang digunakan oleh teks al-Qur'ān atau teolog-teolog Muslim. Dalam teologi Islam perang tidak pernah suci baik sah maupun tidak. ${ }^{27}$

Dari pandangan beberapa pemikir liberal tentang makna kata jihād di atas, dapat dipahami bahwa mereka lebih memilih makna substantif dari jihad daripada makna yang sering didengungkan oleh kalangan skripturalis. Makna substantif yang dimaksud adalah bahwa jihad merupakan perjuangan, perlawanan serius tidak saja pada kekufuran dan kemunafikan tetapi juga pada kesewenang-wenangan dan kebodohan. Singkatnya makna jihād menurut kelompok kedua ini adalah sebuah perjuangan terhadap nilai-nilai kemanusiaan.

\section{Tinjauan Kritis}

Setelah penulis menguraikan model penafsiran kontekstual terhadap teks al-Qur'ān yang berkembang dewasa ini, disertai contoh yang merepresentasikan pandangan kelompok

${ }^{25}$ Sayyid Mahmūd Taleghānī, Society and Economics in Islam, terj. R. Cambell, (Berkeley: Mizan Press, 1982), p. 79.

${ }^{26}$ Muhammad Syahrūr, al-Islām wa al-Imān Manzhūmāt al-Qiyām (Damaskus: Al-Ahali li al-Thiba'ah wa al-Nasyr wa al-Tawzi', 1996), p. 393.

${ }^{27}$ Khaled Abou El Fadl, Cita dan Fakta Toleransi dalam Islam (Bandung: Arasy, 2003), p. 34. 
Mawaizh

Jurnal Dakwah dan Pengembangan Sosial Kemanusiaan

Vol. 11, no. 1 (2020), pp. 1-25.

DOI: https://doi.org/10.32923/maw.v11i1.1203

tersebut, maka untuk lebih mengerucutkan analisa terhadap makna "jihad" dalam konteks kekinian, penulis berusaha melakukan kajian kritis dengan menggunakan dua pendekatan; pertama, pendekatan sejarah atau biasa disebut dengan pendekatan historis dan kedua, pendekatan hermeneutik.

Dengan menggunakan alat bantu berupa dua pendekatan tersebut diharapkan dapat menghadirkan gambaran yang jelas tentang makna "jihad" dalam konteks kekinian.

\section{Pendekatan Sejarah}

Dalam kajian selanjutnya penulis berusaha menerapkan pendekatan sejarah pada tema "jihad" di atas. Sehingga dengan demikian tampak jelas bagaimana pendekatan sejarah ini beroperasi, dan pada gilirannya dapat dijadikan sebuah "metode" untuk menelusuri makna sebuah kata.

Di kalangan umat Islam tidak ada kata-kata yang lebih menggetarkan seperti halnya kata-kata "jihad". Resonansinya bahkan mungkin terasa lebih kuat lagi justru di kalangan umat agama lain. Begitu kata-kata jihad diserukan lazimnya diiringi pekik "Allahu Akbar", maka seakan genderang perlawanan telah ditabuh dan pedang telah dihunuskan. ${ }^{28}$ Pertanyaan yang akan dijawab dalam kajian ini adalah: Bagaimana sesungguhnya konteks historis dari kata "jihad" diungkap oleh al-Qur'ān? Bagaimana pula doktrin "jihad" dipahami oleh umat Islam dari waktu ke waktu?

Dari penelusuran sejarah, khususnya sejarah kronologis turunnya ayat-ayat jihad, pada hakekatnya perintah jihad telah turun melalui ayat-ayat al-Qur'ān semenjak Nabi Muhammad berdakwah Islam di Makkah. Namun pemakaian kata-kata jihad pada periode tersebut tidak bermakna perang atau perlawanan fisik. Kata jihad dalam konteks ayat-ayat Makkiyah-di mana posisi Nabi masih sebagai pemimpin kelompok minoritas di bawah

28 Lihat artikel Masdar F. Mas'udi, "Kontekstualisasi Konsep "Jihad", dalam http://www.islamemansipatoris.com/artikel.php?id=131 
Mawa'izh

Jurnal Dakwah dan Pengembangan Sosial Kemanusiaan

Vol. 11, no. 1 (2020), pp. 1-25.

DOI: https://doi.org/10.32923/maw.v11i1.1203

dominasi masyarakat pagan—dipakai dalam makna perjuangan yang substantif, etis, moral, dan spiritual. ${ }^{29}$

Beberapa ayat yang menyebut kata jihad pada periode Makkah menegaskan akan hal tersebut, yakni makna substantif dari jihad. Hal ini seperti ditegaskan dalam Q.s. alFurqān/25: 52:

$$
\text { فلا تطع الكفرين وجهدهم جهادا كبيرا (الفرقان /25: 52) }
$$

Maka janganlah kamu mengikuti orang-orang kafir, dan berjihadlah dengan jihad yang besar.

Makna kata "jihad yang besar" dalam ayat ini, menurut Ibn 'Abbas seperti dikutip oleh Ibn Katsīr adalah jihad dengan al-Qur'ān. ${ }^{30}$ Adapun menurut al-Zamakhsyarī, pengertian dari kata "jihad yang besar" dalam ayat di atas adalah mencakup segala bentuk perjuangan (jāmi'an likulli mujāhadah). ${ }^{31}$

Dalam ayat lain kata jihad juga disebut bersamaan dengan kata sabar, seperti pada Q.s. al-Nahl/16: 110:

$$
\text { ثمّ إنّ ربّك للَّنين هاجروا من بعد مافتتوا اثمّ جهدوا وصبروا إنّ ربّك من بعدها لغفوررحيم }
$$

Dan sesungguhnya Tuhanmu (pelindung) bagi orang-orang yang berhijrah sesudah menderita cobaan, kemudian mereka berjihad dan sabar; sesungguhnya Tuhanmu sesudah itu benar-benar Maha Pengampun lagi Maha Penyayang.

Mayoritas ulama berpendapat bahwa ayat-ayat yang memuat kata jihad di atas turun di Makkah. Seluruh ayat dalam surat al-Furqān turun di Makkah. Ibn 'Abbās dan Qatadah sebagaimana dikutip oleh al-Zamakhsyarī memberi pengecualian tiga ayat dalam surat alFurqān yang turun di Madinah yaitu ayat 68, 69, dan 70.32 Demikian juga halnya dengan seluruh ayat dalam surat al-Nahl. Mayoritas ulama berpendapat bahwa keseluruhan ayat

${ }^{29}$ Bernard Lewis, The Crisis of Islam; Holy War and Unholy Terror, (London: The Orion Publishing Group, 2003), p. 24.

${ }^{30} \mathrm{Abū}$ al-Fidā' al-H̄āfizh Ibn Katsīr al-Dimasyqī, Tafsīr al-Qur'ān al-'Azhīm, (Beirut: Dār al-Kutub al'Ilmiyyah, 2000), Jilid III, p. 326.

${ }^{31}$ Al-Zamakhsyarī, Al-Kasysyāf, (Kairo : Mushthafa al-Babi al-Halabi, 1996), p. 278.

${ }^{32}$ Al-Zamakhsyarī, Al-Kasysyāf,, (Kairo : Mushthafa al-Babi al-Halabi, 1996), p. 255. 
Mawaizh

Jurnal Dakwah dan Pengembangan Sosial Kemanusiaan

Vol. 11, no. 1 (2020), pp. 1-25.

DOI: https://doi.org/10.32923/maw.v11i1.1203

dalam surat tersebut turun di Makkah. Menurut al-Zamakhsyarī seluruh ayat dalam surat alNahll turun di Makkah kecuali tiga ayat terakhir, yaitu ayat 126-128. ${ }^{33}$

Pandangan mayoritas ulama tersebut diperkuat oleh beberapa ayat tentang jihad lainnya yang turun di Makkah. Seperti terdapat dalam Q., s. al-'Ankabūt/29: 69 yang menyebutkan:

و الّذّن جهدوا فينا لنهدينّه سبلنا... (العنكبوت/29: 69)

Dan orang-orang yang berjihad untuk (mencari keridlaan) Kami, benar-benar akan Kami tunjukkan kepada mereka jalan-jalan Kami.

Makna jihad dalam ayat ini sesuai dengan kondisi sosial umat Islam pada saat di Makkah adalah berjuang (berjihad) di jalan Allah dengan penuh kesabaran, menanggung penderitaan akibat cacian dan siksaan kaum Quraisy. Dengan perjuangan mereka Allah akan memberi petunjuk dan menerangi jalan-jalan-Nya. Dari keterangan ayat-ayat di atas, dapat disimpulkan bahwa ayat-ayat jihad dalam periode Makkah tersebut tidak dalam makna perang tetapi dalam makna dasar jihad, yaitu kesungguhan dan kesusahan dalam mengeluarkan kekuatan dan kemampuan.

Pemaknaan terhadap kata "jihad" mengalami evolusi dan memasuki babak baru setelah Nabi Muhammad hijrah ke Yatsrib (Madinah). Berbeda dengan kondisi umat Islam ketika di Makkah di mana saat itu mereka masih berjumlah sedikit, posisinya lemah, serta marjinal dan tertindas. Di Madinah umat Islam membentuk sebuah struktur sosial yang kuat, sebuah komunitas besar dengan seperangkat norma sosial dan agama yang melingkupinya.

Sejarah mencatat, semenjak di Madinah umat Islam tidak serta merta diizinkan berjuang dalam bentuk peperangan. Selama dua tahun mereka justru diperintahkan untuk berjuang dalam membangun struktur masyarakat dan menjalin kerjasama yang kuat dengan kabilah dan agama lain yang hidup di Madinah. Hal ini dimaksudkan agar terbentuk kesatuan dan keharmonisan hidup di antara seluruh penghuninya. ${ }^{34}$ Aturan-aturan pokok tata

${ }^{33}$ Al-Zamakhsyarī, Al-Kasysyāf, (Kairo : Mushthafa al-Babi al-Halabi, 1996), p. 569.

${ }_{34}$ Muhammad Jamal al-Dīn Surūr, Qiyam al-Dawlah al-'Arabiyah al-Islāmiyyah fì Hayāti Munammad saw, (Cairo: Dār al-Fikr al-'Arabī, 1977), p. 95. 
Mawaizh

Jurnal Dakwah dan Pengembangan Sosial Kemanusiaan

Vol. 11, no. 1 (2020), pp. 1-25.

DOI: https://doi.org/10.32923/maw.v11i1.1203

kehidupan bersama antara umat Islam dengan kabilah dan agama lain ini kemudian dikenal dengan istilah "Piagam Madinah". 35

Baru di tahun kedua setelah hijrah umat Islam diizinkan berperang untuk mempertahankan diri dari serangan musuh. Secara tegas kata perintah yang digunakan dalam ayat-ayat perang tersebut adalah qātilū! (perangilah) bukan jāhidū. Hal ini seperti

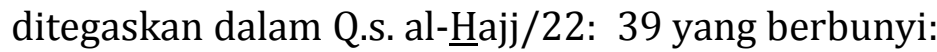

$$
\text { أذن للَّنين يقتلون بأنّهم ظلمو ا وإنّ الله على نصر هم لقدير (الحجّ/22: 39) }
$$

Telah diizinkan (berperang) bagi orang-orang yang diperangi, karena sesungguhnya mereka telah dianiaya. Dan sesungguhnya Allah, benar-benar Maha Kuasa menolong mereka.

Dan juga disebutkan dalam Q., s. al-Baqarah/2: 190:

$$
\text { وقتلو ا في سبيل الله الَّنين يقتلونكم ولا تعتدو ا إنّ الله لايحبّ المعتدين (البقرة/2: 190) }
$$

Dan perangilah di jalan Allah orang-orang yang memerangi kamu, (tetapi) janganlah kamu, melampaui batas, karena sesungguhnya Allah tidak menyukai orang-orang yang melampaui batas.

Dalam Q., s. al-Tawbah/9: 13 juga ditegaskan:

$$
\text { ألا تقتلون قوما نكثوا أيمنهم و همّوا بإخر اج الرّسول وهم بدءوكم أوّل مرّة (التوبة/9: 13) }
$$

Mengapakah kamu tidak memerangi orang-orang yang merusak sumpah (janjinya), padahal mereka telah keras kemauannya untuk mengusir Rasul dan merekalah yang pertama kali memulai memerangi kamu?

Kalau kita cermati, ayat-ayat di atas yang notabene menyerukan perintah perang semuanya menggunakan kata "al-qitāl" (perang) bukan "al-jihād" (berjuang). Penggunaan kata "al-qitāl" ini hemat penulis, memiliki tujuan yang jelas dan mengarah yaitu berperang mempertahankan eksistensi mereka (baca: umat Islam) dari serangan musuh. Dalam hal ini perang yang diserukan oleh al-Qur'ān adalah perang dalam makna defensif (pertahanan diri) bukan ofensif (penyerangan).

35 Ahmad Sukarja, Piagam Madinah dan Undang-Undang Dasar 1945; Kajian Perbandingan tentang Dasar Hidup Bersama dalam Masyarakat yang Majemuk, (Jakarta: UI Press, 1995), p. 2. 
Mawa'izh

Jurnal Dakwah dan Pengembangan Sosial Kemanusiaan

Vol. 11, no. 1 (2020), pp. 1-25.

DOI: https://doi.org/10.32923/maw.v11i1.1203

Berbeda dengan kata "al-qitāl" yang mempunyai tujuan jelas dan mengarah, kata "aljihād" bermakna luas. Dengan demikian meskipun kata "al-jihād" digunakan dalam ayat-ayat al-Qurān periode Madinah maknanya tetap mencakup pelbagai bentuk perjuangan baik psikis, fisik, maupun materi berupa harta benda. Dalam Q.s. al-Hujurāt/49: 15 yang notabene masuk ke dalam kelompok ayat Madaniyah disebutkan:

إنّما المؤ منون الَّ ين امنوا بالهه ورسوله ثمّ لم برتابو اوجهدوا بأمو الهم و أنفسهم في سبيل الله... (الحجرات/49: 15) Sesungguhnya orang-orang yang beriman hanyalah orang-orang yang beriman kepada Allah dan Rasul-Nya kemudian mereka tidak ragu-ragu dan mereka berjihad dengan harta dan jiwa mereka di jalan Allah...

Dari kajian terhadap kronologis ayat-ayat jihad yang disebutkan dalam al-Qur'ān di atas dapat disimpulkan bahwa makna "jihad" yang dimaksud al-Qur'ān sangat multimakna dan kaya perspektif sesuai dengan konteks-konteks kalimat dan konteks sosial kaum muslimin. Dengan demikian, makna jihad tidak dapat "disempitkan" menjadi makna perang. Karena seperti telah disebutkan di atas bahwa perintah perang dalam al-Qur'ān ditegaskan dengan menggunakan kata "al-qitāl". Sehingga kata "al-jihād" yang disebutkan dalam alQur'ān meskipun turun dalam periode Madinah tidak bisa diartikan sebagai perang tetapi dimaknai sebagai perjuangan yang bersifat umum.

\section{Pendekatan Hermeneutik}

Setelah penulis menguraikan pengertian, cara kerja, serta pandangan yang pro dan kontra seputar metode hermeneutik ini, selanjutnya penulis akan mengkaji term "jihad" yang seringkali memicu pertentangan di antara umat Islam. Term "jihad" tersebut akan penulis kaji dengan menggunakan pendekatan hermeneutik.

Term jihad berasal dari bahasa Arab al-jihād. Kata ini berakar pada kata al-juhd atau al-jahd. Dalam beberapa kamus bahasa Arab kata ini dartikan dengan pelbagai pengertian. Ibn Manzhūr dalam Lisān al-'Arab menyebutkan bahwa makna kata al-juhd adalah al-thāqah 
Mawa'izh

Jurnal Dakwah dan Pengembangan Sosial Kemanusiaan

Vol. 11, no. 1 (2020), pp. 1-25.

DOI: https://doi.org/10.32923/maw.v11i1.1203

yaitu kemampuan atau kekuatan. Sedangkan kata al-jahd dimaknai dengan al-masyaqqah yaitu kesulitan. ${ }^{36}$

Dalam kamus al-Munjid kata al-juhd diartikan dengan al-thāqah wa al-istithä'ah yaitu kekuatan dan kemampuan. Sedangkan kata al-jahd dimaknai dengan al-mubālaghah yaitu berlebihan atau juga shu'ūbat kubrā, yaitu kesulitan yang besar. ${ }^{37}$

Definisi al-jihād dalam al-Mu'jam al-Wasith juga tidak jauh berbeda dengan penjelasan yang diungkapkan oleh dua kamus di atas, akan tetapi ada sedikit tambahan. Yaitu al-jahd tidak hanya dimaknai dengan al-masyaqqah atau kesulitan tetapi juga diartikan sebagai alnihāyah wa al-ghāyah yaitu akhir dan tujuan. Sedangkan kata al-juhd dimaknai sebagai alwus'u wa al-thāqah yaitu kemampuan dan kekuatan. ${ }^{38}$ Merujuk pada keterangan beberapa kamus bahasa Arab di atas, maka dapat diambil sebuah kesimpulan bahwa makna jihād yang notabene berasal dari dua kata al-jahd atau al-juhd mengandung pengertian; sebuah usaha mengerahkan kemampuan dan kekuatan untuk mencapai tujuan dengan diliputi pelbagai kesulitan dan kesusahan.

Dalam al-Qur'ān istilah jihād seringkali diikuti oleh kalimat fi sabïlillāh, "di jalan Allah" atau dengan kalimat bi amwāl wa anfus dengan "harta dan diri". Penyematan kalimat $f i$ sabīlillāh dan bi amwāl wa anfus ini pada gilirannya dipahami oleh sebagian umat Islam dengan berjuang di jalan Allah melalui peperangan. Dari sini kemudian terminologi jihād yang semula mencakup muatan universal berupa perjuangan untuk mengubah tatanan individu dan sosial demi kehidupan yang lebih baik lambat laun mengalami penyempitan makna menjadi perang saja. Pada akhirnya jihād kemudian disebut sebagai "perang suci" atas nama Tuhan.

Pemaknaan jihād dalam satu makna yaitu perang telah tertanam secara kuat dalam memori kolektif serta benak umat Islam maupun non-Muslim pada umumnya. Pengertian jihād dipersempit dan disamakan dengan al-qitāl, al-harb dan al-ghazwah, yang

\footnotetext{
36Ibn Manzhūr, Lisān al'Arab, (Beirut: Dar Ihya al-Turats al-'Arabi, 1999), Jilid III, p. 3.

${ }^{37}$ Louis Ma'louf, Al-Munjid fi al-Lughah wa al-A'lam, (Beirut: Dār al-Masyriq, 1986), p. 106.

${ }^{38}$ Ibrāhīm Mushthafā, et..al., al-Mu'jam al-Wasīth, (Istanbul: al-Maktabah al-Islāmiyah, 1972), Cet. ke-
} 2, Jilid 1, p. 142. 
Mawa'izh

Jurnal Dakwah dan Pengembangan Sosial Kemanusiaan

Vol. 11, no. 1 (2020), pp. 1-25.

DOI: https://doi.org/10.32923/maw.v11i1.1203

kesemuanya berarti peperangan dan pertempuran. Kenyataan akan mainstream pemaknaan tunggal terhadap jihād yang diartikan sebagai perang diakui oleh Sa'īd Ramadlān al-Būthī, seorang ulama berkebangsaan Syria yang cukup berpengaruh. Padahal menurut al-Būthī jika jihād diidentikkan dengan perang maka ajaran jihād akan kehilangan makna yang sebenarnya dan segala bentuk variasinya. ${ }^{39}$

Islam sendiri tidak pernah mengakui adanya istilah perang suci (al-harb almuqaddasah). Dalam Islam hanya diakui dua bentuk perang yaitu perang yang disyariatkan (al-harb al-masyrü'ah) dengan tujuan untuk mempertahankan diri (defensif) dan perang yang tidak disyariatkan (al-harb ghayr masyrū'ah).

Menurut Farid Esack Al-Qur'ān memakai kata ini dengan berbagai makna mulai dari peperangan seperti terdapat dalam Q., s. al-Nisā'/4: 90; al-Furqān/25: 52; al-Tawbah/9: 41 sampai perjuangan spiritual kontemplatif, seperti disebutkan dalam Q., s. al-ㅍajj/22: 78; al'Ankabūt/29: 6, dan bahkan paksaan, seperti tertuang dalam Q., s. al-'Ankabūt/29: 8; Luqmān/31: 15. ${ }^{40}$ Lebih lanjut Esack menegaskan bahwa al-Qur'ān menetapkan jihad sebagai jalan untuk menegakkan keadilan, dan praksis sebagai jalan untuk memperoleh dan memahami kebenaran. Dengan demikian menurut Esack, jihād sebagai kunci hermeneutika mengasumsikan bahwa hidup manusia pada dasarnya bersifat praktis, teologi akan mengikuti. ${ }^{41}$

Pandangan Esack tentang makna jihad sebagai jalan untuk menegakkan keadilan seperti membela orang-orang lemah, menghapus kezaliman dan kebatilan (fitnah), dan menegakkan ketaatan ( $\operatorname{din}$ ) yang hanya untuk Allah ini senada dengan apa yang disebut oleh beberapa ayat al-Qur'ān, seperti pada Q., s. al-Nisā/4: 75:

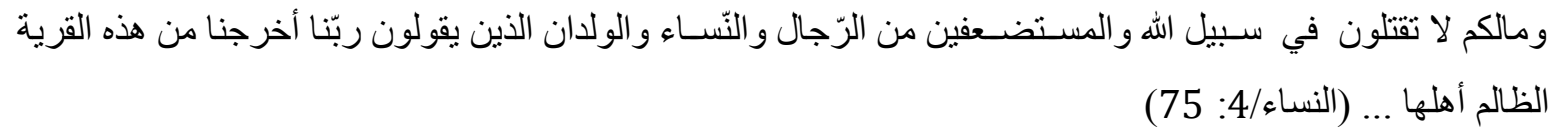

Mengapa kamu tidak mau berperang di jalan Allah dan (membela) orang-orang yang lemah baik laki-laki, perempuan-perempuan maupun anak-anak yang semuanya

${ }^{39}$ Muhamammad Sa'īd Ramadlān al-Būthī, Al-Jihād fĩ al-Islām, (Beirut: Dār al-Fikr al-Mu'āshir, 1993), p. 8.

${ }^{40}$ Farid Esack, Qur'an: Liberation \& Pluralism, (Oxford: One World, 1997), p. 107.

${ }^{41}$ Ibid. 
Mawa'izh

Jurnal Dakwah dan Pengembangan Sosial Kemanusiaan

Vol. 11, no. 1 (2020), pp. 1-25.

DOI: https://doi.org/10.32923/maw.v11i1.1203

berdoa:" Ya Tuhan kami, keluarkanlah kami dari negeri ini (Makkah) yang zalim penduduknya...

Dan juga pada Q., s. al-Baqarah/2: 193 yang menyebutkan:

$$
\text { وقتلو هم حتى لاتكون فتنة ويكون الدّين لله...(البقرة/2: 193) }
$$

Dan perangilah mereka itu, sehingga tidak ada fitnah lagi dan (sehingga) ketaatan itu hanya semata-mata untuk Allah.

Ayat-ayat di atas menegaskan bahwa tujuan jihad di jalan Allah adalah untuk membela kaum yang tertindas (mustadh'afin), menegakkan hak-hak mereka serta menghilangkan "fitnah"42 di muka bumi ini.

Untuk menelusuri evolusi makna kata jihād ada baiknya kita menyimak sebuah penjelasan yang cukup baik dan sistematis yang diungkapkan oleh seorang pemikir Muslim progresif asal Mesir yaitu Muhammad Sa'îd al-Asymawī. Dalam dua buah bukunya yang berbeda yaitu Against Islamic Extremism yang telah dialih bahasakan ke dalam bahasa Indonesia menjadi "Jihad Melawan Islam Ekstrim" dan al-Islām al-Siyāsī, al-Asymawī memaparkan periodisasi evolusi makna jihād sebagai berikut:

Pertama, pada mulanya fase Makkah (610-622 M), kata jihād digunakan dalam pengertian etis, moral dan spiritual dalam konteks indvidu. Jihād di sini berarti menjaga keimanan serta kehormatan seseorang di tengah situasi yang gawat dan sulit.

Kedua, pada fase Madinah (622-632 M), kata jihäd mencakup perjuangan individu dan masyarakat dalam menghadapi kaum musyrik Makkah. Perjuangan di sini dalam bentuk harta (Q.S. al-Tawbah/9: 41) psikis dan spiritual.

Ketiga, pada fase ini kemudian kata jihād mengambil makna baru dalam manifestasinya yaitu berarti perang ( $a l-\underline{h} a r b)$. Sebuah bentuk perlawanan akan agresi yang

42 Mengenai makna "fitnah" dalam ayat di atas, para ulama berbeda pendapat. Menurut Mujadid, Qatadah, al-Dlahhak, dan Ibn Zayd, arti "fitnah" adalah kemusyrikan (al-syirk). Lihat, Ibn Jarīr al-Thabarī, Jāmi' al-Bayān 'an Ta'wīl Āyi al-Qur'ān, (Beirut: Dār al-Fikr, 2001), Jilid II, p. 236-237. Ibn 'Abbās, sebagaimana dikutip al-Rāzī, memaknai "fitnah" dengan kekufuran, karena memiliki dampak kerusakan di muka bumi. "Fitnah" juga dapat berarti "pengusiran" yang dilakukan orang Quraisy terhadap orang Islam dari Makkah. Lihat, Imām alRāzī, Tafsīr Fakhr al-Rāzī, (Beirut: Dār al-Fikr, 1995), Jilid III, p. 142. 
Mawa'izh

Jurnal Dakwah dan Pengembangan Sosial Kemanusiaan

Vol. 11, no. 1 (2020), pp. 1-25.

DOI: https://doi.org/10.32923/maw.v11i1.1203

dilancarkan oleh kaum musyrikin yang ingin menghancurkan eksistensi masyarakat Madinah yang baru terbentuk.

Keempat, pada masa penaklukan kota Makkah (fath Makkah) dan sesudahnya, jihad mengambil bentuk sebagai perang terhadap kaum musyrik Makkah agar mereka mengakui serta beriman kepada Allah dan bersaksi bahwa Muhammad adalah utusan Allah.

Kelima, karena komunitas Yahudi mengkhianati perjanjian yang telah dibuat dan disepakati bersama dengan Nabi, maka pada fase ini jihād berarti peperangan terhadap mereka yang mengingkari serta mengkhianati perjanjian tersebut. Peperangan ini berlanjut sampai akhirnya mereka menunjukkan sikap baik mereka terhadap Nabi dan kaum Muslimin dengan cara membayar upeti (jizyah). Pada gilirannya komunitas mereka kemudian disebut dengan ahl dzimmah.

Keenam, pada akhirnya makna jihād yang orisinil, meskipun ia mengalami perkembangan karena perubahan situasi dan kondisi tertentu adalah perjuangan spiritual, etis dan moral terhadap kesulitan dan kesukaran. ${ }^{43}$

Dari keterangan al-Asymawī ini jelaslah bahwa makna kata jihād mengalami evolusi dan bermetamorfosis sesuai dengan konteks dan kondisi sosial yang berlaku dan terjadi di masyarakat. Dengan demikian maka pemaknaan tunggal yang bersifat parsial terhadap kata jihād ini tidak dapat dibenarkan dan tidak dapat diterima. Karena makna kata jihād bersifat universal sesuai dengan konteks yang melingkupinya.

\section{Kesimpulan}

Setelah penulis mengkaji makna "jihad" dalam al-Qur'an dengan model penafsiran kontekstual yang disertai tinjauan kritis melalui pendekatan sejarah dan hermeneutik, penulis menyimpulkan bahwa makna "jihad" secara kontekstual ini lebih sesuai dengan spirit zaman. Inilah makna "jihad" dalam konteks kekinian.

43 Muhammad Sa'īd al-Asymawī, Jihad Melawan Islam Ekstrem, terj. Hery Haryanto Azumi, (Depok: Desantara, 2002), p. 182-187. Lihat juga dalam bukunya yang lain, Al-Islām al-Siyāsī, (Kairo: Sinā li al-Nasyr, 1987), pp. 105-9. 
Mawa'izh

Jurnal Dakwah dan Pengembangan Sosial Kemanusiaan

Vol. 11, no. 1 (2020), pp. 1-25.

DOI: https://doi.org/10.32923/maw.v11i1.1203

\section{Referensi}

Al-'Āk, Khālid 'Abdurrahmmān, t.th. Al-Furqān wa al-Qur'ān. Beirut: Dār al-Hikmah.

Al-Daghamain, Ziyad Khalil Muhammad. 1995. Manhajiyyah al-Bahtsts fì al-Tafsìr al-Maudhū'ì. Amman: Dār al-Basyar.

al-Dzahabī, Muhammad ㅂusain. 1995. Al-Tafsīr wa al-Mufassirūn. Cairo: Maktabah Wahbah.

Al-Farmāwī, 'Abd al-Hayy, 1977. Al-Bidāyah fì al-Tafsīr al-Mawdlūūī; Dirāsah Manhajiyyah Mawdlū'iyyah. Cairo: Al-Hadhārah al-'Arabiyyah,

al-Rāzī. 1995. Tafsīr Fakhr al-Rāzī. Beirut: Dār al-Fikr.

Al-Qurthubī. 1995. Al-Jāmi' li Ahkām al-Qur'ān. Beirut: Dār al-Fikr.

Al-Zamakhsyarī. 1996. Tafsīr al-Kasysyāf 'an Haqaiq al-Tanzil wa 'Uyun al-Aqawil wa Wujuh al-Ta'wil, Kairo : Mushthafa al-Babi al-Halabi.

Braaten, Carl. 1966. History and Hermeneutics. Philadelphia: Fortress.

Cragg, Kennet. 1971. The Event of the Qur'an: Islam and its Scripture. London: George Allen and Unwin.

E. Sumaryono. 1999. Hermeneutika: Sebuah Metode Filsafat. Yogyakarta: Kanisius.

Eliade, Mircea. 1993. The Encyclopedia of Religion. New York: Macmillan.

Farid Esack. 1997. Qur'an: Liberation \& Pluralism. Oxford: One World.

Hidayat, Komaruddin. 1996. Memahami Bahasa Agama; Sebuah Kajian Hermeneutik. Jakarta: Paramadina.

Katsīr Ibn . Tafsìr al-Qur'ān al-'Azhìm. Beirut : Dar al-Kutub al-'Ilmiyyah.

Manzhūr Ibn. 1999. Lisān al'Arab. Beirut : Dar Ihya al-Turats al-'Arabi.

'Iyāzī, Muhammad 'Ali. 1414 H. Al-Mufassirūn; Hayātuhum wa Manhajuhum. Teheran: Mu'assasah al-Thibā'ah wa al-Nasyr Wizārat al-Tsaqāfah al-Irsyād al-Islāmī.

Kuntowijoyo. 1985. Iman dan Realitas. Yogyakarta: Shalahuddin Press.

Lewis, Bernard. 2003. The Crisis of Islam; Holy War and Unholy Terror. London: The Orion Publishing Group.

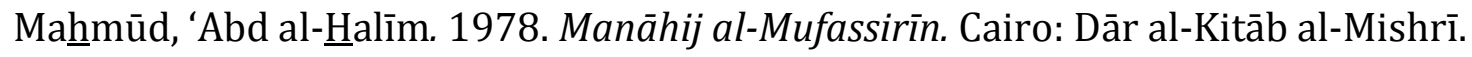


Mawa'izh

Jurnal Dakwah dan Pengembangan Sosial Kemanusiaan

Vol. 11, no. 1 (2020), pp. 1-25.

DOI: https://doi.org/10.32923/maw.v11i1.1203

Muhammad Sa'īd al-Asymawī. 2002. Jihad Melawan Islam Ekstrem. terj. Hery Haryanto Azumi. Depok: Desantara.

Muhammad Sa'īd Ramadlān al-Būthī. 1993. Al-Jihād fì al-Islām. Beirut: Dār al-Fikr alMu'āshir.

Mushthafā, Ibrāhīm. 1972. et..al., al-Mu'jam al-Wasīth. Istanbul: al-Maktabah al-Islāmiyah.

Muslim, Musthafa. 1989. Mabāhits fĩ al-Tafsīr al-Maudhū'ī. Damaskus: Dār al-Qalam.

Ormiston, Gayle L. 1990. Hermeneutic Tradition: From Ast to Ricoeur. New York: SUNNY.

Palmer, Richard E. 1969. Hermeneutics: Interpretation Theory in Schleiermacher, Dilthey, Heidegger, and Gadamer. Evanston: Northwestern University Press.

Surūr, Muhammad Jamal al-Dīn. 1977. Qiyam al-Dawlah al-'Arabiyah al-Islāmiyyah fì Hayāti Muhammad saw. Cairo: Dār al-Fikr al-'Arabī. 